\title{
Material Recording, Scheduling, Dispatching, and Distributing Workers
}

National Cancer Institute

\section{Source}

National Cancer Institute. Material Recording, Scheduling, Dispatching, and Distributing

Workers. NCI Thesaurus. Code C122477.

Workers who compile records concerning quantity, cost, and type of material received, stored or issued, or who schedule and coordinate flow of work within or between departments. 